\title{
Age-related changes and seasonal variations in boar sperm metabolism during liquid storage at $5^{\circ}$ and $16^{\circ} \mathrm{C}$
}

\author{
L. Fraser, K. Gorszczaruk, M. Lecewicz and J. Strzeżek ${ }^{1}$ \\ Warmia and Mazury University in Olsztyn, Faculty of Animal Bioengineering, \\ Department of Animal Biochemistry and Biotechnology \\ Oczapowskiego 5, 10-718 Olsztyn, Poland
}

(Received 2 April 2003; revised version 3 July 2003; accepted 28 October 2003)

\begin{abstract}
In the present study the effect of boar age and seasonal changes on oxygen uptake $\left(\mathrm{ZO}_{2}\right)$ and ATP content in spermatozoa during storage at $5^{\circ}$ and $16^{\circ} \mathrm{C}$ were analysed. Semen was collected from 3 Polish Landrace boars for a 3 -year period. The semen was extended in a standard semen extender, Kortowo 3 (K3), which was supplemented with lipoprotein fractions extracted from hen (K3-LPFh) or ostrich egg yolk (K3-LPFo).

Irrespective of the storage temperatures, lower metabolic activity was manifested in reduced $\mathrm{ZO}_{2}$ values and ATP content in spermatozoa stored in $\mathrm{K} 3$ extender. The metabolic performance of spermatozoa from boars aged 25-36 months was higher, particularly during the autumn-winter period. The addition of lipoprotein fractions to the semen extender had a beneficial effect on the analysed biochemical parameters of the metabolic activity of spermatozoa preserved at $5^{\circ} \mathrm{C}$. This seems to indicate that boar age and the season may be important factors that can influence the use of semen for liquid preservation.
\end{abstract}

KEY WORDS: boar, spermatozoa, oxygen uptake, ATP, extender

\section{INTRODUCTION}

Preservation of liquid boar semen is an important technique in pig reproduction. Sperm metabolism, as well as motility, is disrupted during liquid preservation at different temperatures. Besides sperm motility, the adenosine triphosphate (ATP) content and oxygen consumption are other parameters related to the meta-

\footnotetext{
${ }^{1}$ Corresponding author: e-mail: kbz@uwm.edu.pl
} 
bolic performance of spermatozoa. Sperm progressive movement is an important function that enables spermatozoa to reach the site of fertilization. Propulsion requires an adequate supply of ATP, which can be generated either in the presence of oxygen by respiration coupled with oxidative phosphorylation or anaerobically by fructolysis (Mann, 1964; Mann and Lutwak-Mann, 1981). Dysfunction of the sperm mitochondria may lead to a gradual degree of uncoupling of electron transport from oxidative phosphorylation (Jones, 1997). ATP is necessary for many purposes within the spermatozoa, such as the maintenance of the intracellular milieu by active extrusion of ions and modifications to the structure and function of the cells during maturation, capacitation and fertilization (Jones and Milmlow, 1997). Once in the female reproduction tract, spermatozoa must maintain their motility and for this it is generally assumed that the right amount of ATP is needed.

It has been shown that increasing age may negatively influence reproductive performance in mammals (Colenbrander and Kemp, 1990). Seasonal changes in sperm motility, viability and morphology, as well as in the lipid peroxidation potential of boar semen have been reported (Park and Yi, 2002; Strzeżek et al., 1992). Moreover, maintaining motility and fertility of spermatozoa during liquid storage at $5^{\circ}$ and $16^{\circ} \mathrm{C}$ is an important consideration in the use of liquid boar semen. The fertility of liquid semen is gradually lost during extended periods at different temperatures. Therefore, evaluation of sperm metabolic variables may provide more information about the quality of the extended semen following prolonged storage. The present investigation is a part of our recent study, which has shown that lipoprotein fractions (LPF) extracted from hen or ostrich egg yolk enhanced the motility of liquid-preserved boar spermatozoa (Fraser et al., 2002a). In the presently described study, we investigated the effect of boar age and seasonal variations on oxygen uptake $\left(\mathrm{ZO}_{2}\right)$ and ATP content in spermatozoa stored in a standard extender, supplemented with lipoprotein fractions extracted from hen or ostrich egg yolk, at $5^{\circ}$ and $16^{\circ} \mathrm{C}$.

\section{MATERIAL AND METHODS}

\section{Semen collections and assessment}

Three Polish Landrace boars, aged 8 months, were used in this experiment. The boars were housed under the same conditions and were given a commercial porcine ration. Water was available ad libitum. Ejaculates, collected from the boars over a 29-months from February 1999 through June 2001, were used for analysis of metabolic parameters. The gloved-hand technique was used to collect the ejaculates.

Routine semen analysis was performed using a light microscope to determine sperm concentration, motility and morphology. Semen samples were extended in 
a standard boar extender, Kortowo 3 (K3). The K3 extender was supplemented with lipoprotein fractions extracted from hen (K3-LPFh) or ostrich egg yolk (K3-LPFo), as described in previous studies (Demianowicz and Strzeżek, 1996; Strzeżek et al., 1998).

The semen samples were diluted with K3, K3-LPFh, and K3-LPFo extenders and were dispersed into $100-\mathrm{ml}$ plastic bottles. Following equilibration for $2 \mathrm{~h}$ at room temperature, the samples were stored at $5^{\circ} \mathrm{C}$ (Refrigerator) and $16^{\circ} \mathrm{C}$ (Thermobox).

\section{Measurements of oxygen uptake}

Oxygen uptake was measured in fresh semen and in extended semen samples (K3; K3-LPFh; K3-LPFo) on Day 0 (D0), Day 2 (D2) and Day 3 (D3) of storage at 5 and $16^{\circ} \mathrm{C}$. The YSI Model 5300 Biological Oxygen Monitor (Yellow Springs Instrument Co., Inc., Yellow Springs, Ohio, USA) equipped with a Clarke-type polographic oxygen probe immersed in a magnetically stirred sample chamber was used to measure oxygen uptake by spermatozoa. Sperm suspensions $(3 \mathrm{ml})$ were placed into the oxygen chamber and gently stirred for $5 \mathrm{~min}$ and measurements were performed at $100 \%$ air saturation at $37^{\circ} \mathrm{C}$. Calculations of the oxygen probe measurements were conducted according to the manufacturer's instruction manual. Oxygen uptake was expressed as $\mathrm{ZO}_{2}$ which is equivalent to $\mu \mathrm{l} \mathrm{O}_{2}$ consumed by $10^{8}$ spermatozoa in $1 \mathrm{~h}$ at $37^{\circ} \mathrm{C}$.

\section{Measurements of ATP content}

ATP contents were measured in fresh semen samples and in K3-, K3-LPFh-, and K3-LPFo-extended semen samples on D0, D2 and D3 of storage at $5^{\circ}$ and $16^{\circ} \mathrm{C}$. Sperm extracts obtained by homogenization of cell pellets with perchloric acid, followed by centrifugation and neutralization, were used to measure the ATP content as described by Adam (1965). Spectrophotometric measurements of ATP content were determined at a wavelength of $366 \mathrm{~nm}$. The values were expressed as nmol ATP $/ 10^{8}$ spermatozoa.

\section{Statistical analysis}

All values obtained were expressed as means \pm standard deviation (SD). Student's t-test was used to compare parameters within the age groups (8-24 months and 25-36 months) and seasonal periods (autumn-winter and spring-summer). Means among different extenders, within the respective storage periods, were compared using Duncan's multiple comparison test. Calculations were carried out using the STATISTICA computer package (STATISTICA for Windows, StatSoft 
Incorporation, Tulsa, OK). A value of $\mathrm{P} \leq 0.05$ was chosen as an indication of statistical significance.

\section{RESULTS AND DISCUSSION}

In fresh semen samples there were no significant changes $(\mathrm{P} \geq 0.05)$ in oxygen consumption or ATP levels regardless of animal age or seasonal periods (Table 1). A similar trend was observed for diluted semen following $2 \mathrm{~h}$ equilibration at room temperature (D0, data not shown). However, $\mathrm{ZO}_{2}$ values and ATP content in spermatozoa were higher than those of fresh semen samples, irrespective of the extender type, animal age or seasonal period. The initial increase in the metabolic variables was due to the "dilution effect", a phenomenon common for boar spermatozoa after the dilution process. A previous study showed that the "dilution effect" might be associated with changes in plasma membrane permeability and release of enzymes from sperm structures (Strzeżek et al., 1984).

TABLE 1

Oxygen uptake and ATP content of fresh, unextended boar semen used for liquid storage (means $\pm \mathrm{SD})$

\begin{tabular}{lcccc}
\hline Indices & Age/Season & $\begin{array}{c}\text { Number } \\
\text { of ejaculates }\end{array}$ & $\begin{array}{c}\text { Oxygen uptake } \\
\mu \mathrm{O} \mathrm{O}_{2} / 10^{8} / 1 \mathrm{~h} / 37^{\circ} \mathrm{C}\end{array}$ & $\begin{array}{c}\text { ATP content } \\
\mathrm{nmol} / 10^{8} \mathrm{spz} .\end{array}$ \\
\hline $\begin{array}{l}\text { Age of } \\
\text { boars }\end{array}$ & $8-24$ months & 46 & $14.69 \pm 2.17$ & $13.34 \pm 2.10$ \\
& $25-36$ months & 34 & $15.46 \pm 3.07$ & $15.21 \pm 2.66$ \\
Season & Autumn/Winter & 42 & $15.79 \pm 2.62$ & $14.61 \pm 1.94$ \\
& Spring/Summer & 38 & $15.63 \pm 2.34$ & $14.78 \pm 2.96$ \\
\hline
\end{tabular}

Tables 2 and 3 show that prolonged storage caused a gradual decline in oxygen uptake and ATP content in spermatozoa stored at $5^{\circ} \mathrm{C}$, regardless of the extender type. However, spermatozoa from boars aged 25-36 months had a higher $(\mathrm{P} \leq 0.05)$ oxygen uptake and ATP content in LPF-based extenders on D2 of storage at $5^{\circ} \mathrm{C}$ (Table 2). Compared with the spring-summer period, a significantly higher $(\mathrm{P} \leq 0.05)$ ATP content was observed during the autumn-winter period when spermatozoa were stored in the LPF-based extenders on D2 at $5^{\circ} \mathrm{C}$ (Table 3). However, the decline in ATP content occurred, irrespective of whether the spermatozoa were stored at $5^{\circ}$ and $16^{\circ} \mathrm{C}$. It was observed that spermatozoa stored in $\mathrm{K} 3$ extender exhibited lower $(\mathrm{P} \leq 0.05) \mathrm{ZO}_{2}$ values and ATP content, particularly on D2 of storage. Furthermore, the values of $\mathrm{ZO}_{2}$ for the LPF-extended semen stored at $16^{\circ} \mathrm{C}$ were higher than those of fresh semen regardless of animal age or seasonal period. These higher $\mathrm{ZO}_{2}$ values were not related to reduced ATP 


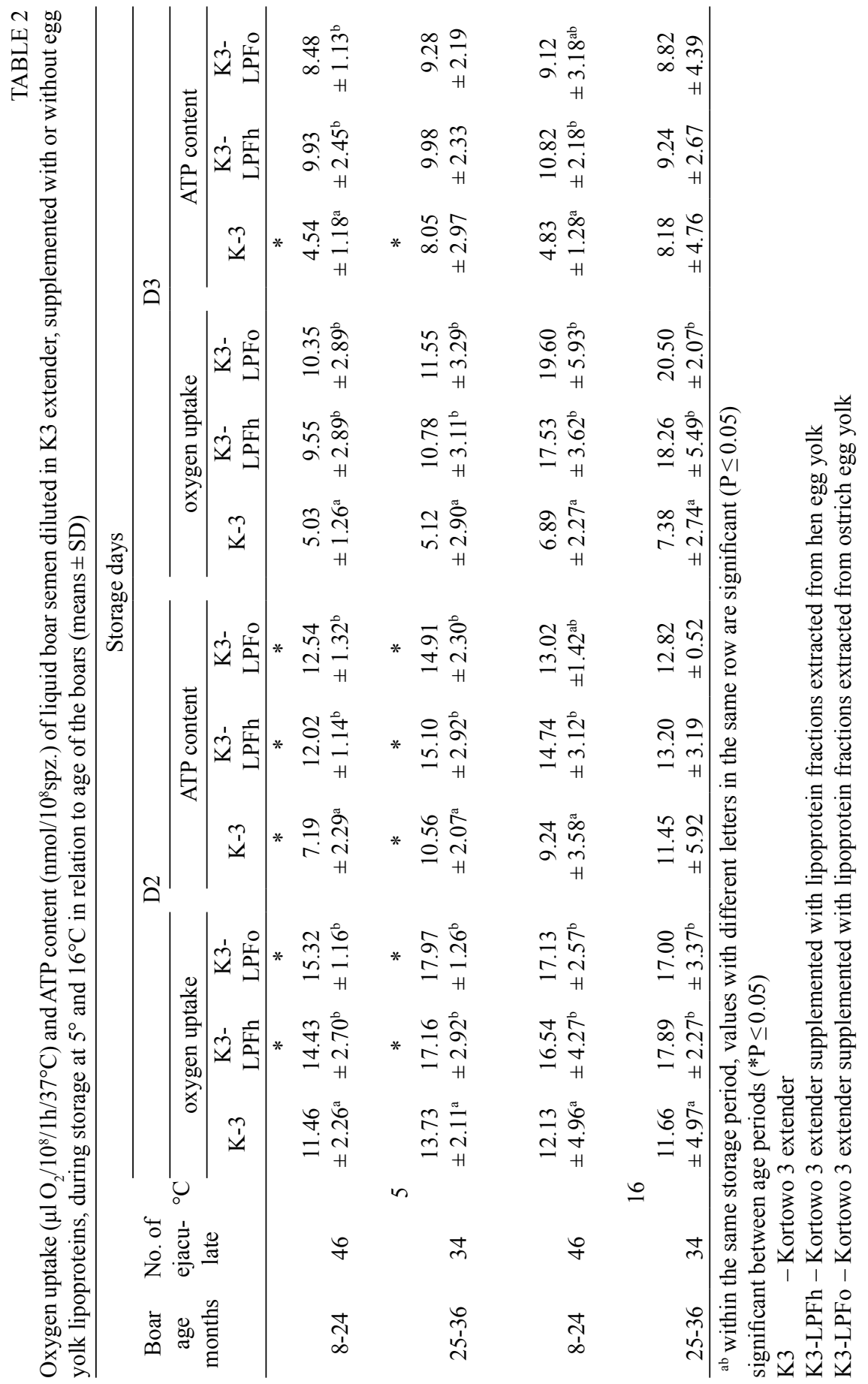




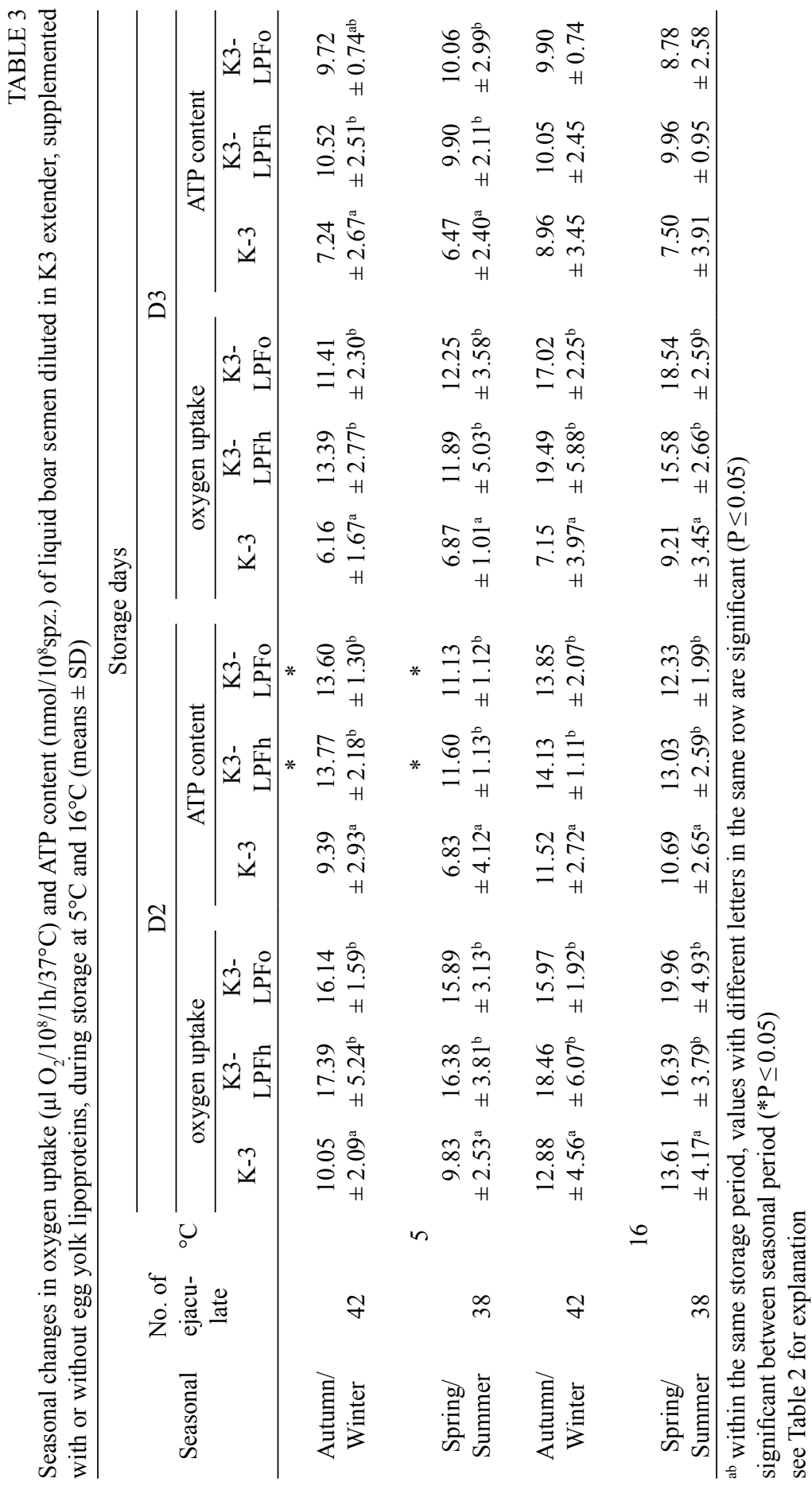


content, and might be indicative of uncoupled oxidative phosphorylation. Similar observations were reported by Aalbers et al. (1961). It should be noted that individual variation in sperm metabolic performance among the boars was observed. The reason for individual boar variability in metabolic activity is unclear, but it could be related to the inherent susceptibility of the mitochondria to oxidative damage during in vitro storage. Individual variations in the metabolic characteristics of boar spermatozoa were also reported in a previous study (Strzeżek et al., 1979).

Even though there were variations in sperm oxidative respiration during storage, there were no significant differences between K3-LPFh- and K3-LPFoextended semen. Moreover, the generation of ATP by mitochondria is vital for the survival of a sperm cell because it is the primary or only source of ATP, and the levels of ATP that its mitochondria produce are often indicative of the cell's functions. During liquid storage spermatozoa lose their ability to generate ATP through mitochondrial respiration as a consequence of mitochondrial ageing. A decrease in the activity of the mitochondria and a loss of ATP during prolonged liquid semen storage has been shown to have a detrimental effect on sperm motility (Fraser et al., 2002b).

Spermatozoa are protected mainly from oxidative insult by seminal plasma, which contains mostly low-molecular weight antioxidants (Strzeżek, 2002). During semen dilution, spermatozoa are removed from the seminal plasma and are deprived of their antioxidant properties, which made them more vulnerable to oxidative attack. There are several proposed mechanisms accounting for the decline in sperm metabolic activity related to oxidative stress. Moreover, lipid peroxidation has been shown to play a key role in the ageing of spermatozoa by limiting their life time during liquid storage (Vishwanath and Shannon, 1997; Cerolini et al., 2000). Spermatozoa stored in $\mathrm{K} 3$ extender at $5^{\circ} \mathrm{C}$ were more susceptible to cold shock (Fraser et al., 2002a), and were probably more vulnerable to oxidative attack. It has been shown that fluidity is related to integrity of the sperm plasma membrane lipids, and changes in the lipid composition of the plasma membrane may therefore be associated with cooling and storage effects (Buhr et al., 1989). Furthermore, the plasma membranes of boar spermatozoa contain a high amount of polyunsaturated fatty acids (De Leeuw et al., 1991), and are therefore susceptible to peroxidation changes, with subsequent loss of membrane integrity, impaired cell function, and decreased sperm motility. In the present study, the lower rate of oxygen consumption and reduced ATP content in K3 extender might be associated with excessive breakdown of membrane phospholipids of spermatozoa during storage, particularly at $5^{\circ} \mathrm{C}$. Vishwanath and Shannon (1997) postulated that in vitro storage of boar semen at different temperatures did not completely arrest sperm metabolism, but the accumulation of the toxic products could have a deleterious effect on sperm metabolic activity. 


\section{CONCLUSIONS}

The results of this study show that the addition of lipoprotein fractions to boar semen extender had a beneficial effect on sperm metabolic activity during liquid storage. It seems that age-related changes and seasonal variation may affect the metabolic performance of preserved spermatozoa regardless of the extender composition. However, it can be suggested that measurement of oxygen uptake and ATP content can provide valuable information about the metabolic status of liquid boar semen during storage at different temperatures. The pig industry would benefit greatly from further in-depth studies to determine the mechanisms of action involved in dysfunction of sperm mitochondria during liquid semen storage or the freeze-thawing process.

\section{REFERENCES}

Aalbers J.G., Mann T., Polge C., 1961. Metabolism of boar semen in relation to sperm motility and survival. J. Reprod. Fertil. 2, 42-53

Adam H., 1965. Adenosine-5'-triphosphate determination with phosphoglycerate kinase. In: H.U. Bergmeyer (Editor). Methods of Enzymatic Analysis. Verlag Chemie, Academic Press, New York, London, pp. 539-543

Buhr M.M., Canvin A.T., Bailey J.L., 1989. Effects of semen preservation on boar spermatozoa head membranes. Gamete Res. 23, 441-449

Cerolini S., Maldjian A., Surai P., Noble R., 2000. Viability, susceptibility to peroxidation and fatty acid composition of boar semen during liquid storage. Anim. Reprod. Sci. 58, 99-111

Colenbrander B., Kemp B., 1990. Factors influencing semen quality in pigs. J. Reprod. Fertil., Suppl. 40, 105-115

De Leeuw F.E., Colenbrander B., Verkleij AJ., 1991. The role membrane damage plays in cold and freezing injury. Reprod. Domest. Anim., Suppl. 1, 95-104

Demianowicz W., Strzeżek J., 1996. The effect of lipoprotein fraction from egg yolk on some of the biological properties of boar spermatozoa during storage of the semen in liquid state. Reprod. Domest. Anim. 31, 279-280

Fraser L., Lecewicz M., Krasicki R., Strzeżek J., 2002a. Effect of extender composition and storage temperatures on motility of preserved boar semen. J. Anim. Feed Sci.11, 661-669

Fraser L., Lecewicz M., Strzeżek J., 2002b. Fluorometric assessments of viability and mitochondrial status of boar spermatozoa following liquid storage. Pol. J. Vet. Sci. 5, 85-92

Jones A.R., 1997. Metabolic activity of hypotonically treated mature boar spermatozoa. Reprod. Fert. Develop. 9, 583-586

Jones A.R., Milmlow D., 1997. Endogenous energy production by mature boar spermatozoa. J. Reprod. Fertil. 111, 285-290

Mann T., 1964. Metabolism of semen: fructolysis, respiration and sperm energetics. In: T. Mann (Editor). The Biochemistry of Semen and of the Male Reproductive Tract. London, Methuen and Co. LTD, pp. 265-307

Mann T., Lutwak-Mann C., 1981. Chemical and metabolism characteristics of ejaculated spermatozoa: comparative viewpoint. In: T. Mann, C. Lutwak-Mann (Editors). Male Reproductive Function and 
Semen: Themes and Trends in Physiology, Biochemistry and Investigative Andrology. SpringerVerlag, Berlin, New York, pp. 195-216

Park C.S., Yi Y.J., 2002. Comparison of semen characteristics, sperm freezability and testosterone concentration between Duroc and Yorkshire boars during seasons. Anim. Reprod. Sci. 73, 53-61

Strzeżek J., 2002. Secretory activity of boar seminal vesicle glands. Reprod. Biol. 2, 243-266

Strzeżek J., Demianowicz W., Luberda Z., Torska J., 1992. The effect of season on acrosin activity and plasmalemma susceptibility of boar spermatozoa. Proceedings of the 12th International Congress on Animal Reproduction, Hague (The Netherlands) 4, 532-534

Strzeżek J., Fraser L., Hołody D., Wysocki P., 1998. Biochemical properties and usefulness of boar semen for liquid preservation following atropine administration. J. Vet. Med. A 45, 459-470

Strzeżek J., Glogowski J., Magierska E., Luberda Z., Jabłonowska C., 1984. Some aspects of cryobiochemistry of boar semen.. Proceedings of the 10th International Congress on Animal Reproduction and Artificial Insemination. University of Illinois (USA), pp. 244-246

Strzeżek J., Śmigielska J., Liminowicz J., Czeczot H., Głogowski J., 1979. The metabolism of boar semen preserved in different diluents at $18^{\circ}-20^{\circ} \mathrm{C}$ (in Polish). Proceedings of the $16^{\text {th }}$ Scientific Session on Physiology and Pathology. Reproduction Section, PTWN, Part 2, pp. 153-162

Vishwanath R., Shannon P., 1997. Do sperm cells age? A review of the physiological damages in sperm during storage at ambient temperatures. Reprod. Fert. Develop. 9, 321-331

\section{STRESZCZENIE}

\section{Zmiany aktywności metabolicznej plemników konserwowanych w stanie płynnym w tempe- raturze $5^{\circ}$ i $16^{\circ} \mathrm{C}$, z uwzględnieniem wieku knurów i pory roku}

Analizowano wpływ wieku knura i pory roku na zużycie tlenu $\left(\mathrm{ZO}_{2}\right)$ i zawartość ATP w długotrwale przechowywanych plemnikach w stanie płynnym w temperaturze $5^{\circ}$ i $16^{\circ} \mathrm{C}$. Nasienie pobierano od 3 knurów rasy pbz przez 3 lata. Do konserwacji nasienia stosowano licencjonowany rozcieńczalnik Kortowo-3 (K3), którego skład wzbogacano dodatkiem frakcji lipoproteinowej izolowanej z żółtka jaja kury (K3-LPFh) lub strusia afrykańskiego (K3-LPFo).

Stwierdzono, że niezależnie od temperatury konserwacji, aktywność metaboliczna plemników przechowywanych w rozcieńczalniku K3 bez dodatku LPF była wyraźnie obniżona, co przejawiało się niskimi wartościami współczynnika $\mathrm{ZO}_{2}$ oraz zawartością ATP. Najwyższą sprawność metaboliczną wykazywały plemniki pobierane od knurów w wieku 25-36 miesięcy, zwłaszcza w okresie jesienno-zimowym. Wykazano korzystny wpływ dodatku lipoprotein żółtkowych do rozcieńczalnika na analizowane parametry biochemiczne metabolizmu plemników konserwowanych $\mathrm{w}$ temperaturze $5^{\circ} \mathrm{C}$. Wyniki badań wskazują że wiek knurów i pora roku mogą być istotnymi czynnikami wpływającymi na przydatności nasienia do konserwacji w stanie płynnym. 